\title{
Yerli ve Yabancı Gazetelerde Büyükelçi Krizi
}

\section{The Ambassador Crises in Local and Foreign Newspapers}

\author{
Dr. Öğr. Üyesi Nermin Zahide AYDIN (iD)1
}

$\ddot{\mathbf{O z}}$

Türkiye, İkinci Dünya Savaşı'ndan sonra Batılı Devletler ile ittifak kurmak istedi. Bu nedenle Ortadoğu'da ayrı bir savunma sisteminin oluşturulması için çalıştı. Mısır ise bölgenin lideri olmak istiyordu. Bu nedenle Mısır, İngiltere'yi Süveyş bölgesinden çekmek istedi. Fakat Türk yetkililer Mısır'ın bu isteğini onaylamadı. Kısa bir süre sonra Mısır ile Türkiye arasında büyükelçi krizi ortaya çıktı. Hulusi Fuat Tugay 1951 yılında Kahire'ye büyükelçi olarak gönderilmişti. Hulusi Fuat Tugay'ın eşinin Mısır Hanedanlığı ile akrabalık ilişkileri vardı. Büyükelçinin eşinin mallarına Mısır Hükümeti tarafından el konuldu. Hulusi Fuat Tugay buna tepki gösterdi. Kısa bir süre sonra Mısır yöneticileri tarafından sınır dışı edildi. Büyükelçi krizi ile ilgili haberler yerli ve yabancı basında yer aldı. Mısır basınına göre olay büyükelçiye yönelikti. Türk basını ise olayı, diplomatik yetersizlik olarak değerlendirdi. Çalışmamızda yerli ve yabancı basında yer alan haberler, büyükelçi krizinin nedenleri ve sonuçları incelendi.

Anahtar Kelimeler: Türkiye, Mısır, Hulusi Fuat Tugay, büyükelçi

Makale Türü: Araştırma

\begin{abstract}
After the Second World War, Turkey wanted to establish an alliance with Western States. Thus he worked to establish a separate defense system in the Middle East. Egypt wanted to be leader of the region. For this reason Egypt wanted to withdraw England from Suez region. But the Turkish authorities did not approve to the Egypt of request. The ambassador crisis emerged between Turkey and Egypt shortly after. In 1951 Hulusi Fuat Tugay was sent to Cairo as an ambassador. Hulusi Fuat Tugay's wife had kinship relations with the Egyptian dynasty. The goods of his wife were confiscated by the Egypt Government. Hulusi Fuat Tugay reacted to this. After a short while, he was deported by the Egyptian rulers. News about the ambassador crisis took place at the local and foreign press. According to the Egyptian press, the incident was directed to the ambassador. TheTurkish press was regarded as diplomatic inability. In our study were examined the news in local and foreign press, the causes and consequences of the ambassador crises.
\end{abstract}

Keywords: Turkey, Egypt, Hulusi Fuat Tugay, ambassador

Paper Type: Research

${ }^{1}$ Kilis 7 Aralık Üniversitesi, Muallim Rıfat Eğitim Fakültesi, nzahideaydin@ hotmail.com.

Atıf için (to cite): Aydın, N. Z. (2019). Yerli ve Yabancı Gazetelerde Büyükelçi Krizi. Afyon Kocatepe Üniversitesi Sosyal Bilimler Dergisi, 21(3), 753-763. 


\section{Giriș}

İkinci Dünya Savaşı'ndan sonra Süveyş Kanalı'nı elinde bulundurmak isteyen İngiltere, askeri ittifak yapılmasının gerekli olduğunu savundu. Bu nedenle Amerika, Fransa ve Türkiye ile ortak bir ittifak kurdu. Kisa bir süre sonra dört devlet tarafından 13 Ekim 1951'de Misır Hükümeti'ne bir nota verildi. Misır Hükümeti, hem notayı reddetti hem de15 Ekim 1951'de kabul ettiği kanunlarla 1936 tarihli İngiltere-Mısır Süveyş Anlaşması'nı feshetti. Yarbay Abdülnasır başkanlığındaki Hür Subaylar Komitesi, 23 Temmuz 1952 günü yaptıkları bir darbe ile Mısır'da krallığa son vererek yönetimi ele geçirdi. 28 Temmuz'da İskenderiye'de tahtından feragate zorlanan Kral Faruk (Armaoğlu, Tarihsiz, 495-496), ülkesinden ayrilarak Avusturyalı bir asilzade grubu tarafından kulüp haline getirilmiş olan Mittersil Şatosunda ikamet etmeye başladı (Akşam Gazetesi, 2 Ocak 1954).

Kendi liderliğinde bir Arap birliği kurmak isteyen Misır Hükümeti (Ataoğlu, 2008: 91), hedefine ulaşmak için Batı karşıtı bir politika izledi. Süveyş Meselesi, Yarbay Nasır'ın Sovyet Rusya'ya yönelmesine neden oldu (Armaoğlu, Tarihsiz: 492). Ortadoğu'da Türkiye'nin faaliyetlerinden rahatsızlık duyan Misır ile (Tuna, 2002: 254) Türkiye arasında Ortadoğu'nun siyasal haritasını belirleyecek bir güç mücadelesi başladı (Fırat ve Kürkçüoğlu, 2004: 621). Sovyetler Birliği, İngiliz-Mısır ticaretinin asgari seviyeye inmesi üzerine meydana gelen boşluğu doldurmak için her türlü ithal maddesi göndermeye hazır olduğunu belirtti. Bunun karşılığında ise Mısır'ın Sovyetler Birliği'ne karşı kurulacak hiçbir Batılı devletler paktına veya anlaşmasına iştirak etmeyeceği hususunda teminat vermesini şart koştu (Akşam Gazetesi, 6 Ocak 1954). Mısır ile Sovyetler Birliği arasındaki ilişkiler farklı bir boyut kazanarak devam ederken, Türkiye'nin Ortadoğu politikasının yürütülmesinde işbirliği için Yarbay Nasır'la olan diyaloğa yeteri kadar önem vermemesi, Türk dış politikasında birtakım sıkıntıların yaşanmasına neden oldu (Yavuzalp, 1991: 73).

\section{Türkiye İle Mısır Arasında Yaşanan Büyükelçi Krizi}

Müşir Deli Fuat Paşa'nın oğlu olan Çerkez asıllı Hulusi Fuat Tugay asker, diplomat ve tıp doktoruydu. Osmanlı Genelkurmayı tarafından Birinci Dünya Savaşı devam ederken 11 Ekim 1916'da karışıklığın giderilmesi ve askerlerin sağlık durumları hakkında sağlıklı bilgiler alınması için Viyana'ya Avusturya-Macaristan Hastaneleri Müfettişi unvanıyla gönderildi (Dağlar, 2006, 59). Dışişlerinde diplomat olarak Kopenhag, Tokyo, Nanking gibi şehirlerde çalıştıktan sonra Tiran elçiliğine 29 Ocak 1938 tarihinde tayin edildi (CCA, 82.8.10, 30.18.1.2). Çalıştı̆g 1 süre dikkate alınarak derecesi yükseltildi (CCA, 118.4.1, 30.11.1.0). Tiran'da çalıştıktan sonra Madrid orta elçiliğine atandı (Ulus Gazetesi, 6 Ağustos 1939). Bir süre sonra Portekiz Hükümeti nezdinde Türkiye'yi temsil etmesi için görevlendirildi (CCA, 88.95.12, 30.18.1.2; Ulus Gazetesi, 9 Ekim 1939). Madrid'de çalıştı̆̆ süre içinde derecesi yükseltildi (CCA, 161.15.6,30.11.1.0). Buradaki görevini yerine getirdikten sonra sırasıyla Çunking (Ulus Gazetesi, 21 Ocak 1944) ve Bükreş’te çalıştı. Ocak 1951'de Kahire Büyükelçiliğine tayin edildi (Milliyet Gazetesi, 5 Ocak 1954). Kahire'de Şevket Fuat Keçeci'nin yerine gelen Hulusi Fuat Tugay, çalışanlarına dürüst ve şefkatli davrandı (Milliyet Gazetesi, 27 Ocak 1980).

Misır'da Kral Faruk'un ve ailesine mensup olanların tüm emlakine el konulmasina izin veren Müsadere Kanunu'nun yürürlüğe girmesinden sonra Türkiye ile Mısır arasındaki ilişkiler bozuldu (Baş, 2015: 182). Kral Faruk'a ait olan eşyalar o kadar değerliydi ki değeri 4000 dolar olan ve bir eşi Amerika'da bulunan İtalyan pulu da müsadere edilen eşyalar arasında yer aldı (Akşam Gazetesi, 2 Ocak 1954). Hulusi Fuat Tugay’ın eşi Emine Hanım, Mısır kralı Faruk'un kuzeni olup (Milliyet Gazetesi, 5 Ocak 1954), aynı zamanda Mehmet Ali hanedanının bir üyesiydi (The Northern Miner, 7 Ocak 1954). Bu nedenle kendisine ait mallara Mısır Hükümeti tarafindan el konuldu (The Mercury, 6 Ocak 1954 Çarşamba). Müsadere Kanunu, hem Hulusi Fuat Tugay ile Hür Subaylar Komitesi arasındaki gerginliğin artmasına, hem de soğuk bir şekilde süren Türkiye-Mısır ilişkilerinin kötüleşmesine sebep oldu (Baş, 2015: 182). 
Müsadere Kanunu ile büyükelçi ve Mısırlı yöneticiler arasında gerginlik devam ederken Hulusi Fuat Tugay'in Misır Devrimci Konsey Komutanına “Gururlanmayın. Napolyon'a ve onun karşılaştı̆̆ kadere bakın. Ülkenizi mahvedeceksiniz" dediği iddia edildi (Queensland Times, 6 Ocak 1954; The Examiner, 8 Ocak 1954). Büyükelçi ile Mısırlı yöneticiler arasında yaşanan gerginlik üzerine Misır Hükümeti tarafından Türk Hükümetine bir nota verilerek büyükelçinin geri alınması ima edildi. Türk Dışişleri Bakanlığı tarafından Tugay'ın birkaç gün Mısır'da kaldıktan sonra ayrılacağı Mısır Hükümetine bildirildi. Fakat bu birkaç günlük ikametin bir buçuk ay uzaması üzerine (Akşam Gazetesi, 6 Ocak 1954) Mısır Hükümeti, Türkiye'nin Kahire büyükelçisi Hulusi Fuat Tugay'ın diplomatik dokunulmazlığını kaldırarak, 24 saat içinde ülkeyi terk etmesini istedi. Mısırlı yönetici Hasan Ebu Seud, bu kararın alınmasında büyükelçinin eşinin Mehmet Ali hanedanına mensup olmasının önemli bir etken olduğunu vurguladı. Mısırlı yöneticileri rahatsız eden diğer bir konu ise yılbaşı gecesi Türkiye Büyükelçiliği'’nde düzenlenen kabul törenine hiçbir Mısırlı şahsiyetin davet edilmemesi ve büyükelçi Tugay'ın "Beni bir daha bu pis yerde görmeyeceksiniz" şeklinde bir ifade kullanmasıydı. Büyükelçi Tugay'ın Kahire operasında kendisini karşılayan Başbakan yardımcısı Abdülnasır'a "Hareketleriniz bir centilmene yakışmayacak hareketlerdir. Onun için aramızda hiçbir zaman dostluk olmayacaktır." gibi sözler sarf etmesi de Mısırlı yöneticilerin bu kararı almasında etkili oldu (Akşam Gazetesi, 5 Ocak 1954). Misırlı yöneticilere göre Hulusi Fuat Tugay görevini layıkıyla yerine getirememiş, bir diplomata yaraşmayacak davranışlarda bulunmuş (Milliyet Gazetesi, 6 Ocak 1954), Kral Faruk'un kuzeni olan karısının mallarına el konulmasından dolayı Türkiye'nin siyasetine şahsi bir yön verdirtmişti (Akşam Gazetesi, 5 Ocak 1954). Üstelik Hulusi Fuat Tugay'ın Müsadere Kanunu'nun uluslararası hukuka aykırı olduğunu belirten açıklaması da Mısır Hükümeti tarafından Mısır'ın aleyhinde verilmiş bir beyanat olarak kabul edildi (Milliyet Gazetesi, 23 Kasım 1953).

\section{Hulusi Fuat Tugay'ın Kahire'den Ayrılışı}

1951'den beri Kahire Büyükelçisi olan Hulusi Fuat Tugay, Mısır Hükümeti tarafından (Examiner, 6 Ocak 1954), tüm diplomatik hakları ve ayrıcalıkları elinden alınarak 24 saat içinde ülkeyi terk etmeye zorlandı (Newcastle Morning Herald And Miners Advocate, 20 Ocak 1954). 5 Ocak'ta sürgün edilen (The Courier-Mail, 20 Ocak 1954) Hulusi Fuat Tugay, Kahire Hava Meydanı'ndan uçakla ayrıldı (Milliyet Gazetesi, 6 Ocak 1954). Mısır Hükümeti'nden hiç kimsenin yolcu etmediği (Akşam Gazetesi, 6 Ocak 1954) Büyükelçi Tugay, Kahire Ulusal Havaalanında İngiliz Büyükelçisi Sir Ralph Stevenson ve Belçika Büyükelçisi tarafından uğurlandı (The West Australian, 6 Ocak 1954). Hulusi Fuat Tugay, Kahire'den ayrilmadan önce verdiği beyanatta Mısır Hükümeti'nin kararını çocukça bir hareket olarak değerlendirerek, Mısır Hükümeti'nin diplomatik sahada acemi olduğunu, bu hadisenin iki ülke arasındaki diplomatik münasebetlerin kesilmesine neden olmayacağını tahmin ettiğini söyledi. Mısırlı gümrük memurları, Kahire Havaalanı'nda Türkiye Büyükelçisinin bavullarındaki eşyaları çıkarıp masa üzerine sererek (Milliyet Gazetesi, 6 Ocak 1954), çantalarını aradı (Barrier Miner, 7 Ocak 1954). Foto muhabirleri gümrük salonuna alınarak, gümrük memurlarının yaptıkları bu hareketi resmetmeleri sağlandı (Milliyet Gazetesi, 6 Ocak 1954). Tugay, gümrüğe 100 Amerikan doları, 600 İsviçre Frang1 ve 9 Mısır lirasının olduğunu bildirdi. Mısır yönetmeliklerine göre kendisi ile birlikte sadece 20 Mısır Lirasına eşdeğer para almasına izin verildi. Paranın geri kalanı bir Türk büyükelçiliği yetkilisine emanet edildi (Newcastle Morning, 6 Ocak 1954).

Misırlı yöneticiler tarafindan eleştirilen Hulusi Fuat Tugay (Queensland Times, 6 Ocak 1954 Çarşamba), Kahire'den ayrılarak Beyrut'a geldi (Akşam Gazetesi, 6 Ocak 1954). Daha sonra İstanbul'a hareket etti (Akşam Gazetesi, 8 Ocak 1954). Alanda bulunan gazetecilere son hadiselere dair hiçbir şey söylemeyerek bu hususta konuşmak istemedi (Milliyet Gazetesi, 8 Ocak 1954). Bütün gün Pera Palas'ta istirahat ettikten sonra (Akşam Gazetesi, 8 Ocak 1954) akşamüstü trenle Ankara'ya hareket etti (Milliyet Gazetesi, 8 Ocak 1954). Burada kendisi ile görüşen gazetecilere Dışişleri Bakanlığı ile temas etmeden hiçbir beyanat veremeyeceğini 
tekrarladı. Görüştüğü devlet yetkililerine yaşanan hadise hakkında bilgi verdi (Akşam Gazetesi, 8 Ocak 1954).

Basında, sınır dışı edilen Türkiye Büyükelçisinin eşi Emine Tugay hakkında 107 bin Mısır lirasına tekâmül eden döviz kaçakçılığı ile ilgili soruşturma açılacağına dair haberler yer aldı. İstanbul'da bulunan Emine Tugay bu haber üzerine gazetecilere ne 107 bin Misır lirasinın ne de dışarı para çıkarmak gibi bir durumun söz konusu olmadığını belirtti. Ayrıca eşinin İstanbul'da olduğu için şimdilik Mısır'a dönme niyetlerinin bulunmadığını, ilerde ne yapacakları konusunda da bir şey söyleyemeyeceğini ifade etti (Milliyet Gazetesi, 8 Ocak 1954).

Mısır Hükümeti, Türkiye büyükelçisi hakkındaki sınır dışı etme kararının Türk-Mısır ilişsileri üzerindeki olumsuz etkisini tahmin etmekteydi (Akşam Gazetesi, 6 Ocak 1954). Nitekim Türk Dışişleri Bakanı, Mısır Hükümeti'ni Türkiye'den Hulusi Fuat Tugay’ı geri çağırmasını istemediği için eleştirdi. (The West Australian, 9 Ocak 1954). Mısır'a bir nota verilerek olay protesto edildi. Notada Türkiye'nin siyasi münasebetlerde dürüstlüğü ilke edindiği belirtilerek, aynı dürüstlüğü diğer devletlerden de beklediği ifade edildi (Milliyet Gazetesi, 8 Ocak 1954). Aslında Hulusi Fuat Tugay, sağlık sebeplerini mazeret göstererek kendisinin bu vazifeden alınmasını Dışişleri Bakanlığı'ndan istemişti. Büyükelçinin isteği Bakanlık tarafından incelendikten sonra Tugay'ın geri çağnılmasına karar verilmiş ve bu karar Mısır Hükümeti'ne bildirilmişti. Büyükelçinin, işlerini düzenlemek için Kahire'ye gittiği sırada Mısır Hükümeti'nin kendisini 24 saat içinde sınır dışı etme kararını açıklaması, Türkiye Hükümeti tarafından tepkiyle karşılandı (Akşam Gazetesi, 6 Ocak 1954). Bakanlık yetkilileri tarafından Mısır Hükümeti'nin böyle bir karara varmasının ve uluslararası kaidelere aykırı bir yol izlemesinin üzüntü verici bir hareket olduğu ifade edildi. Çok geçmeden Misır Büyükelçisi Ahmet Hakkı'nın Türkiye'den ayrılmak üzere hazırlıklara başladığı söylense de büyükelçi geri çağrıldığına dair haberlerin gerçek olmadığını ifade etti (Milliyet Gazetesi, 6 Ocak 1954; Akşam Gazetesi, 6 Ocak 1954).

Mısır Hükümeti'nin Türk Hükümeti'ne karşı aldığı karar Türkiye'deki yabancı elçiliklerde şaşkınlık ve üzüntü ile karşılandı (Akşam Gazetesi, 6 Ocak 1954). Yabancı elçiliklerde Mısır idarecilerinin Türkiye'yi hedef alarak, temsilcisine karşı bile bile böyle bir hareketi yapmış olma ihtimali üzerinde duruldu (Milliyet Gazetesi, 6 Ocak 1954). Suudi Arabistan'ın Ankara büyükelçisi Tevfik Hamza her iki tarafın da durumun düzelmesi için ellerinden geleni yapacaklarına inandığını söyledi. Tevfik Hamza’ya göre Türkiye Şark ile ilişkilerini güçlendirmek için çabalasa da bu yakınlaşmayı istemeyenler vardı (Milliyet Gazetesi, 8 Ocak 1954).

\section{Yerli ve Yabancı Gazetelerde Büyükelçi Krizi}

Mısır gazetelerinde Türkiye Büyükelçisinin sınır dışı edilmesi ile ilgili haberler geniş yer buldu (Akşam Gazetesi, 6 Ocak 1954). Nasır'a yakın gazetecilerden Muhammed Hasanayn Heykel, büyükelçi Tugay'1 Mısır'ın içişlerine karışmakla suçladı (Baş, 2015: 182). El-Mısri gazetesinde ise Hulusi Fuat Tugay'ın uluslararası diplomatik kaidelere uymadığı, Misır Hükümeti’nin Mehmet Ali Sülalesi hakkında aldığı kararın Hulusi Fuat Tugay’ı diplomatlık hüviyetinden çıararak herhangi bir şahıs gibi konuşmasına neden olduğu belirtildi (Milliyet Gazetesi, 25 Kasım 1953). Kahire'nin en büyük gazetesi olan El-Cumhuriyet gazetesinde "Gitti, kurtulduk" başlıklı bir makale yayınladı. BBC radyosunun muhabiri, Mısır Hükümeti'nin de kendi elçisini geri çekme kararını aldığını bildirdi (Milliyet Gazetesi, 6 Ocak 1954).

Times gazetesinde, büyükelçi krizinin Mısır'ın iddia ettiği şekilde gerçekleşmediğine dair haberler yer ald1 (Milliyet Gazetesi, 8 Ocak 1954). Times gazetesinin Kahire'deki muhabirine göre Mısır'ın, Türkiye elçisine karşı sert muamele etmesinin nedeni Süveyş Kanalı müzakereleriydi (Akşam Gazetesi, 6 Ocak 1954). İngiltere, Ortadoğu'nun güvenliği için Türkiye'ye saldırı olduğu takdirde hızlı bir şekilde Süveyş Kanalı'ndan ve üssünden tekrar faydalanılmasını istemekteydi. Mısırlı idareciler ise yalnız Arap memleketlerine saldırı halinde 
İngiltere'nin yeniden eski üssünü kullanmasına müsaade edeceklerini bildirmişti. Times muhabirine göre İngiliz teklifini etkisiz bırakmak maksadı ile Mısır Hükümeti, Türkiye Büyükelçisi'ne karşı bu şekilde hareket etmişti. Çünkü Mısır Hükümeti, Türkiye'nin buna vereceği karşılığın gayet sert olacağını tahmin etmekteydi. Böylelikle Mısır'ın, Türkiye ile Süveyş arasındaki bağları tamamıyla koparması mümkün olabilecekti (Milliyet Gazetesi, 6 Ocak 1954). Üstelik Times gazetesinin Kahire muhabirine göre, Mısır Hükümetinin Türk büyükelçisini itham eden tebliği ile Kahire'deki mevcut raporlar arasında tezatlar bulunmaktaydı. Örneğin Misırlı yöneticilere göre Türk büyükelçisi centilmen değildi. Fakat Türkiye büyükelçisine ve eşine Mısır basınında yapılan saldırılarda ve haksız ithamlarda da centilmence hareket edilmemişti. Ayrıca Mısır basını, Büyükelçi Hulusi Fuat Tugay'ı hava alanında İngiltere Büyükelçisinin yolcu etmesini protesto etmişti. İngiliz Dışişleri Vekâlet sözcüsünün basın konferansında kendisine bu protesto ile alakalı bir soru sorulduğunda sözcü, kendisinin diplomatik terbiye kurallarına göre hareket ettiğini söyledi (Milliyet Gazetesi,7 Ocak 1954). Manchester Guardian gazetesinde Mısır Hükümeti tarafından alınan bu kararın izahının mümkün olmadığını belirtilirken (Milliyet Gazetesi,7 Ocak 1954), Daily Telegraph gazetesinde Orta Doğu bölgesindeki önemli bir devletin temsilcisine karşı yapılan bu hareketin dünya siyasetinde büyük tepkilere neden olacağı ifade edildi (Milliyet Gazetesi, 8 Ocak 1954). Gazetede yer alan haberlere göre Misır Hükümeti'nin uluslararası siyaseti kişiselleştirmesi tamamıla yersiz bir hareketti (Milliyet Gazetesi,7 Ocak 1954).

Büyükelçi krizi ile ilgili olarak Zafer gazetesinde, kamuoyunun Mısır Hükümeti’nin içişlerinde dilediği gibi hareket etmesinin doğal görebileceği, fakat ihtilal hükümeti sıfatı ile dahi hiçbir hükümetin dış münasebetlerinde devletler hukuku kaidelerini ihlal etmesinin maruz görülemeyeceği şeklinde haberler yer aldı (Milliyet Gazetesi,7 Ocak 1954).

\section{Büyükelçi Krizinin Nedenleri}

Batı ile Doğu arasında bir tarafsızlık politikası kurmak isteyen Mısır, Sovyet Rusya ve Çin'le ticari münasebetler kurmak için heyetler gönderdi. Mısır'ın Batı memleketleri ile olan münasebetlerinde de yeni politikasına uygun bir ayarlama yapması gerekti. Mısır Hükümeti'nin Türkiye'ye karşı takip ettiği bu aşırı derecede sert politikası her şeyden önce Mısır'ın Doğu ile yakınlaşmasının bir neticesi olarak görüldü. Diğer önemli sebep ise Mısır'da yıllardan beri Türkiye'ye karşı oluşturulmaya çalışılan mesafeli duruştan kaynaklandı. İngiltere ile Mısır arasında gerçekleşen Süveyş görüşmelerinde İngiltere'nin Türkiye'nin saldırıya uğraması halinde Süveyş'i yeniden işgal etmek için taleplerde bulunması da aynı şekilde Türkiye'nin aleyhine kullanılmak istendi. Bunun yanı sıra iç meselelerin geniş tesirleri de krizin çıkmasında etkili oldu. Mısır'da kral ailesine karşı girişilen hareketler büyükelçinin eşini de ilgilendirdiğinden Türk-Mısır münasebetlerinin bozulmasını arzu eden çevreler bu durumu kullanmaktan çekinmedi (Akşam Gazetesi, 6 Ocak 1954).

Mısır'ın Türk büyükelçisine bu şekilde muamelede bulunması, bazı çevrelerde Arap birliğindeki durumunu kuvvetlendirmek için girişilmiş bir hareket olabileceği şeklinde yorumlandı. Çünkü Misırlı yöneticiler, Arap Birliği idarecileri arasında başlayacak olan konferansta liderliği ele geçirmek için bazı üyelerle görüşmeler yapmıştı (Akşam Gazetesi, 8 Ocak 1954; Milliyet Gazetesi, 8 Ocak 1954). Albay Nasır, El-Cumhuriyet gazetesine verdiği beyanatta Türkiye'nin Arap davaları aleyhinde olduğunu belirttikten sonra Türkiye ile işbirliği yapmayacaklarını çünkü Türkiye'nin 1951 yılında İngiltere, Amerika ve Fransa ile birlikte Orta Doğu Paktı Projesi üzerinde 1srar ettiğini bundan dolayı kendilerini kızdırdığını ifade etti (Milliyet Gazetesi, 8 Ocak 1954).

Hulusi Fuat Tugay'ın sınır dışı edilmesini protesto eden Türk notası Mısır Dışş̧̧leri Bakanlığı'na geldikten sonra Mısır Başvekil Muavini Albay Abdülnasır, Hulusi Fuat Tugay'ın Kahire Hükümeti'ne Orta Doğu Savunma Paktı'nı ve Süveyş Kanalı hakkındaki tasarıyı kabul ettirmeye çalıştığından dolayı Mısırlıları tahrik etmiş olduğunu belirtti (Akşam Gazetesi, 8 Ocak 1954). Bu arada Mısır'da Türkiye'ye karşı olarak Camiülezher'de okumakta olan 100'e yakın 
Türk öğrenciye verilen yemeklerin kalitesi ve miktarı azaltıldı (Milliyet Gazetesi, 11 Ocak 1954).

\section{Mısır Elçiliğinin Tebliği}

Mısır Büyükelçisi ise hadisenin Türkiye'ye karşı yapılmadığını vurgulayarak konuyla ilgili hazırladığı tebliğin Anadolu Ajansı vasıtası ile yayınlanmasını sağladı. Tebliğde Mısır Hükümeti tarafından Hulusi Fuat Tugay hakkında verilen kararın Mısır'ın Türkiye'ye karşı yönelen düşmanca yaklaşımı şeklinde değerlendirilmesinin tamamı ile hatalı olduğu, ülkesinin Türkiye hakkındaki dostluğu daima muhafaza etmek istediği, Mısır Hükümeti tarafından alınmış olan tedbirlerin Türk Hükümeti'ne sataşmayı ihtiva etmediği yer aldı. Mısır Hükümeti'nin bu tedbirleri almış olmasının tek sebebinin Hulusi Fuat Tugay'ın birbirini takip eden gayri dostane hareketlerinden ve Mısır Hükümeti erkânı hakkında takınmış bulunduğu tavırdan kaynaklandığı ifade edildi. Yerli ve yabancı çevreler, Mısır Hükümeti'nin hareket tarzının ancak siyasi gaf tabiri ile vasıflandırılabileceği hususunda hemfikirdi. Aynı çevreler bu hareketin neden olduğu tepkinin Mısır elçiliğini yukarıdaki tebliği yayına mecbur ettiğini belirtmekte fakat bunun Mısır Hükümeti'nin yarattığı gergin havayı yumuşatmaktan uzak olduğunu ifade etmekteydi (Milliyet, 9 Ocak 1954; Akşam Gazetesi, 9 Ocak 1954). Siyasi çevrelere göre Mısır elçiliğinin yayınladığı bu tebliğ, Mısır Hükümeti'nin cevabi notasını vermeden önce, bir zemin yoklaması mahiyetindeydi (Milliyet Gazetesi, 10 Ocak 1954).

\section{Büyükelçi Krizinin Türk Yetkili Makamlarında Görüşülmesi}

Türkiye Dışişleri Bakanlığı, Hulusi Fuat Tugay’ın diplomatik dokunulmazlıklarının kaldırılarak sınır dış1 edilmesi üzerine konuyu etraflı şekilde görüşerek resmi bir tebliğ yayınladı. Dışişleri Bakanlığı'na davet edilen Mısır Büyükelçisine de hükümetine verilmek üzere bir nota verildi. Bakanlık yetkilileri, Hulusi Fuat Tugay'ın yaptığı öne sürülen ve şikâyet konusu olan bazı hareketlerin olduğunu doğrulamakla beraber, Mısır yönetiminin büyükelçiye karşı takınmış olduğu tavrı uygun görmedi. Hadisenin esası, bir sefire karşı yapılan muamelenin temsil ettiği devlet ve milleti kapsaması ve iki memleket arasındaki münasebetlerin diplomatik olmayan hareketlerle hiçe sayılmasıydı. Mısır Hükümeti'ne verilen notada olayın bu yönüne dikkat çekildi (Akşam Gazetesi, 7 Ocak 1954).

Paris radyosu, Türk büyükelçisinin Mısır'dan sınır dışı edilmesi ile ilgili olarak Türkiye'nin yayınladığı tebliği "Türkiye, Misır Hükümetini protesto etmiyor" başlı̆g 1 ile duyurdu. Diğer taraftan Londra radyosu da aynı tebliği “Ankara Kahire'ye protesto notası göndermeyecek" şeklinde yayınladı (Milliyet Gazetesi,7 Ocak 1954). Esasen Türk Hükümeti, Mısır'dan özür beklemekteydi. Eğer Türk Hükümeti'nin bu beklentisi karşılanmazsa daha farklı planlar hayata geçirilecekti (Newcastle Morning Herald And Miners Advocate, 20 Ocak 1954). Bazı çevrelere göre eğer Mısır, Türk notasını reddederse Ankara' daki büyükelçisi Ahmet Hakkı istenmeyen kişi ilan edilecek ve Mısır'ın büyükelçisini derhal geri çekmesi istenecekti (Milliyet, 9 Ocak 1954).

Kısa bir süre sonra olay meclise yansıdı. Giresun Milletvekili Arif Hikmet Pamukoğlu Meclis'te konunun görüşülmesini istedi. Mardin Milletvekili Kamil Boran da meclis riyasetine verdiği bir önergede büyükelçinin Mısır'dan sınır dışı edilmesi karşısında Dışişleri Bakanı'nın kifayeti hakkında Başbakanın düşüncelerini sordu (Akşam Gazetesi, 9 Ocak 1954; Milliyet Gazetesi, 9 Ocak 1954). Köylü Partisi de konu ile ilgili bir gensoru talebinde bulundu (Milliyet Gazetesi, 15 Ocak 1954). Remzi Oğuz Arık ve arkadaşları tarafından verilen önergede Dışişleri Bakanı'ndan gensoru açılması istendi. Önergede Mısır devleti nezdinde Mısır'da meydana gelen son rejim değişikliğinin icap ve ikazlarına ve eski hanedanla olan yakınlığına rağmen büyükelçinin vaktinde geri alınmamasının sebebi soruldu. Diğer taraftan Cumhuriyet Halk Partisi Meclis Grubu da bu mevzuda bir gensoru önergesinin Meclis Başkanlığı'na verilmesini prensip olarak kabul ederek önerge metnini hazırlamak üzere grup idare heyetini görevlendirdi (Akşam Gazetesi, 14 Ocak 1954; Milliyet Gazetesi, 14 Ocak 1954). Cumhuriyet Halk Partisi Genel Sekreteri Kasım Gülek, bu durumun iki hükümetin arasını bozmamasını temenni ettikten 
sonra (Milliyet Gazetesi, 14 Ocak 1954), ülkeyi temsil eden bir büyükelçinin milletlerarası geleneklere ve usullere aykırı olarak sınır dışı edilmesinin Mısır Hükümeti tarafından işlenmiş büyük bir hata olduğunu vurguladı (Akşam Gazetesi, 14 Ocak 1954). Kısa bir süre sonra hazırlanan gensorunun daha kapsamlı olmasına karar verildi (Milliyet Gazetesi, 15 Ocak 1954). İdare heyetinin hazırladığı gensoru önergesi toplantıda görüşülerek son şeklini aldı ve Meclis Başkanlığı'na verildi. Bu önergede Dışişleri Bakanlığı'nın resmi tebliğine göre milletlerarası kaidelere aykırı olarak Türk büyükelçinin siyasi muafiyetleri de kaldırılmak sureti ile Mısır'dan ihraç edilmesi hadisesine temas edildi. Dışişleri Bakanı Fuat Köprülü’nün Mısır Dışişleri nezdinde süratle müdahalede bulunduğuna ve alınacak cevaba göre Meclise ve halk efkârına ikinci bir açıklamada bulunulacağına dair Meclis'teki beyanı hatırlatıldı (Milliyet Gazetesi, 19 Ocak 1954; Akşam Gazetesi, 19 Ocak 1954).

Cumhuriyet Halk Partisi Mardin Milletvekili Aziz Uraz, meselenin partiler üstü bir memleket işi olması nedeni ile gizli bir celsede konuşulması gerektiğini vurguladı (Akşam Gazetesi, 7 Ocak 1954). Vekiller Heyeti, Çankaya Köşkü’nde Cumhurbaşkanı Celal Bayar'ın başkanlığında 5 saat süren bir toplantı yaptı (Milliyet Gazetesi, 15 Ocak 1954). Demokrat Parti Meclis grubunun yaptığı gizli toplantıda, Mısır hadisesi dolayısı ile verilen bir takririn okunması üzerine, Hariciye Vekili kürsüye gelerek Mısır Hükümeti'ne verilen notaya cevap beklendiğini ve bu notanın gelişini müteakip Grup ve Meclis önünde lüzumlu açıklamayı yapacağını söyledi. Bunun üzerine Profesör Sadri Maksudi Arsal ve Dr. Burhanettin Onat söz alarak, hadisenin vahameti üzerinde durdular. Sadri Maksudi, Mısır Hükümeti'nin hareketine karşlık olmak üzere ve notanın cevabını beklemeden Ankara'daki Mısır sefirinin derhal iade edilmesini istedi. Memleket itibarını sarsıcı mahiyetteki hadisede gerekli tedbirlerin alınmadığını belirtti. Burhanettin Onat, durumun hisle değil, vakar ve sükûnetle incelenmesini temenni ederek Mısır'dan başka diğer bazı Arap memleketlerinde de Türkiye'ye karşı son zamanlarda hissedilecek derecede düşmanca hareketler gözlendiğini ifade etti. Dışişleri Bakanlığının Müslüman ülkelerle daha sıkı ilişkiler kurmasını tavsiye etti (Akşam Gazetesi, 13 Ocak 1954). Eleştiriler üzerine Dışişleri Bakanı Fuat Köprülü, Hariciyeyi hedef tutarak ileri sürülen ihmal kelimesini yersiz bulduğunu ifade etti (Milliyet Gazetesi, 7 Ocak 1954). Fuat Köprülü, Demokrat Parti Hükümetlerinin gerek Batı camiası ve gerekse Şark memleketleri ile daima dostane ve hareketli bir dış politika takip ettiğini, Demokrat Parti iktidarlarının Atlantik Paktı ve Kore meselesi gibi konularda başarılı bir politika izlediğini belirtti. Türkiye'nin dış itibarının eskisine oranla çok artmış olduğunu hatırlatan Fuat Köprülü, bu yüzden Batılı ve Doğulu birçok devlet adamının ziyarete geldiğini ifade ederek yabancı devletlerle imzalanan ticari kültürel anlaşmalarını ve Balkan Paktı'nı örnek olarak gösterdi. Mısır'ın elçimize karşı davranışını üzüntü veren bir durum olarak nitelendiren Fuat Köprülü, hükümetin bu meseleye aktif bir şekilde müdahale etmiş olduğunu ve Türkiye'nin dış münasebetlerinde daima dürüstlüğü ilke edindiğini, dost devletlerden de aynı dürüstlüğü beklediğini ifade etti (Milliyet Gazetesi, 13 Ocak 1954). Bu açıklamalardan sonra Balıkesir Milletvekili Müfit Erkuyumcu'nun verdiği bir önerge üzerine Mısır'dan alınacak cevaba göre hareket edilmesi kararlaştırılarak oturuma son verildi (Akşam Gazetesi, 13 Ocak 1954) ve gündemde başka mevzu bulunmadığı için grup dağıldı. Hulusi Fuat Tugay, Dışişleri Bakanlığına tekrar gelerek Fuat Köprülü ile bir müddet görüştü. Büyükelçi öğleden sonra da Umumi Kâtip Cevat Açıkalın'ın nezdinde yapılan bir toplantıya katıldı (Milliyet Gazetesi, 13 Ocak 1954). Hulusi Fuat Tugay, toplantıdan sonra bakanlıktan talimat almadığını ve ancak talimata göre hareket edebileceğini söyledi (Milliyet Gazetesi, 9 Ocak 1954).

Meclis Dışişleri Komisyonu da, Dışişleri Bakanının katılmadığı bir toplantı yaptı. Toplantıda komisyon reisinin birkaç gün önce Mısır meselesi konusunda bir gazeteye verdiği beyanatı görüşüldü. Samsun Milletvekili Firuz Kesim'in TBMM Dişişleri Komisyonu Reisi sıfatı ile Vatan Gazetesine verdiği beyanat, gazetenin 8 Ocak 1954 tarihli nüshasında yayınlanmıştı. Beyanatta, Türkiye-Mısır siyasi münasebetleri hakkında ve gizli bir celsede Dışişleri Bakanının verdiği izahatın dinlendiği, hükümetin bundan bir buçuk ay evvel çirkin bir neşriyat üzerine büyükelçinin başka yere tayinine karar verdiği, fakat büyükelçinin bir müddet 
daha Mısır'da kalmasının uygun görüldügü ile ilgili bilgiler yer almaktaydı. Bunun üzerine Komisyon tarafından toplantı sonunda bir tebliğ yayınlandı. Komisyonun esas itibarı ile hükümetin hareket sahasına giren bir konuda bir karar telkin ettiği kanaatinin oluştuğu, Teşkilatı Esasiye Kanunu'nun ve iç tüzüğün sarih hükümleri karşısında böyle bir müdahalenin söz konusu olamayacağı bildirildi. İlaveten komisyon reisinin, reis sıfatı ile vereceği her türlü beyanatın bir komisyon kararına istinat ettirmesinin içtüzüğün hükümlerinin gereği olduğu, ortada böyle bir karar olmadığına göre söz konusu beyanatın ancak kendi şahsi fikirleri olarak kabul edilmesinin zaruri olacağı kanaatine varıldığı beyan edildi (Milliyet Gazetesi, 12 Ocak 1954).

\section{Demokrat Parti Grubu'nda Mısır Hadisesi İle İlgili Gensoruların Görüşülmesi}

Kahire büyükelçisi Hulusi Fuat Tugay'ın Mısır'dan çıkarılması ile ortaya çıkan hadise hakkında gerek Cumhuriyet Halk Partisi gerekse Köylü Partisi tarafindan Meclis'e verilen gensorular Demokrat Parti Meclis grubunda görüşüldü. İlk sözü alan Dışişleri Bakanı Fuat Köprülü, Kahire'ye verilen son notanın henüz cevabının alınmadığını, bu cevap gelince umumi heyete vaziyeti bütün ayrıntılarıyla anlatacağını beyan etti. Türkiye'nin dıș itibarını yaralayacak bir halin olmadığını ve henüz açığa çıkmamış diplomatik bir mevzu üzerinde Mecliste aleni görüşmeler açılmasının son derece mahsurlu olacağını sözlerine ilave etti (Akşam Gazetesi, 20 Ocak 1954). Ankara Milletvekili Abdullah Gedikoğlu, Mısır Hükümeti'nin hareketini çirkin bulmakla beraber eşi kral hanedanına mensup büyükelçinin önceden geri çekilmesi gerektiğini söyledi. Burhanettin Onat, Hariciyenin son senelerde birçok başarılar elde ettiğini fakat Şark İslam memleketlerine yeteri kadar önem vermediğini söyledi. Bunu bir hata olarak vasıflandırarak din ve kültür beraberliğimiz bulunan bu devletlerin bize hakiki birer dost olabileceklerini ileri sürdü. Her şeyden evvel meselenin tamamının aydınlanmasını beklemeden bir gensoruyu Meclis'e getirmenin zamansız olduğunu belirten Adnan Menderes, iki hükümet arasındaki diplomatik haberleşmenin henüz devam ettiğini, netice alınmadan meselenin meclise getirilmesinin siyasi menfaat bakımından doğru olmayacağını ileri sürdü (Milliyet Gazetesi, 20 Ocak 1954). Adnan Menderes'ten sonra söz alan Fuat Köprülü, hükümetin bu konuda azami hassasiyetle harekete geçtiğini söyledi. Köprülü’nün konuşmasından sonra, Köylü Partisi ve Halk Partisi tarafından verilmiş olan gensoru önergesi oya sunuldu (Milliyet Gazetesi, 20 Ocak 1954). Misır meselesine ait Cumhuriyet Halk Partisi ve Köylü Partisi tarafından verilmiş olan gensoru önergeleri okunduktan sonra gensoru önergelerinin her ikisi de reddedildi (Milliyet Gazetesi, 26 Ocak 1954). Cumhuriyet Halk Partisi Meclis Grubu Reis Vekili Ahmet Barutçu bir gensorunun reddinin o gensorunun cevabı anlamına gelmediğini, demokratik hükümetlerin muhalefetin gensorusundan kaçamayacaklarını ifade etti (Milliyet Gazetesi, 21 Ocak 1954).

\section{Mısır Hükümeti’nin Türk Notasına Karşı Cevabi Notası}

Mısır Büyükelçisi, Dışişleri Bakanı Fuat Köprülü'yü ziyaret ederek Mısır Hükümeti’nin notasını verdi. Cevabi notada Misır Hükümeti'nin Hulusi Fuat Tugay’1 Mısır'1 terke zorlamak için anılan kararını verirken hiçbir zaman Türkiye'ye karşı hakaret kastı gütmediği, Türkiye Mısır dostluğunun iki memleket için de faydalı olacağına inanıldığı belirtildi. İlaveten Mısır Hükümeti'nin büyükelçi Hulusi Fuat Tugay'ın Mısır'ı terke zorlamadan bir ay önce Türkiye Hükümeti'ne müracaatla büyükelçinin geri çağrılmasını talep ettiğini, bu talebin yerine getirilmemesi üzerine ve operadaki skandalın meydana gelmesinden sonra bu kararın alındığ belirtildi. Ayrıca Mısır Büyükelçisi Hulusi Fuat Tugay'ın Mısır'ı terke mecbur edilmesi ile doğan durumu, Mısır Hükümeti ile büyükelçi arasında cereyan eden şahsi bir mesele telakki edildiğini, Mısır Hükümeti anılan kararı ile Türkiye Cumhuriyeti'ne karşı bir hakaret kastı gütmemiş olduğundan Türkiye'den özür dilemek lüzumunu görmediği belirtildi. Notada verilecek bir özrün, Mısır'ın Türkiye'ye hakaret etmiş olduğunu üstü örtülü olarak itiraf etmek olacağını, Mısır Hükümetinin bu kararı alırken asla böyle bir gaye gütmediği ifade edildi. (Milliyet Gazetesi, 12 Ocak 1954). İlaveten notada Türk-Mısır münasebetlerinde en ufak bir değişikliğin mevzu bahis olamayacağı belirtildi (Akşam Gazetesi, 10 Ocak 1954). 
Kahire'de yayınlanan gazetelerde Mısır Hükümetinin son Türk notasına cevap verdiği ve böylelikle büyükelçi Hulusi Fuat Tugay'ın sınır dışı edilmesi ile ortaya çıkan hadiseye kapanmış olarak bakıldığı yazıldı. Fakat Türkiye Büyükelçiliği'nin bir sözcüsü hadisenin kapanmadığını, Mısır gazetelerinin hadiseyi kapanmış gibi gösteren haberleri yayınlarken yalnız kendi arzularını dile getirdiklerini söyledi (Akşam Gazetesi, 17 Ocak 1954). Çok geçmeden eski Kahire büyükelçisi Hulusi Fuat Tugay, Dışişleri Bakanlığına bir dilekçe vererek bu tebliğlerle şahsi itibarının ve meslek haysiyetinin rencide edildiğini ileri sürdü ve emekliliğini istedi (Milliyet Gazetesi, 18 Nisan,1954).

Türkiye Ortadoğu'da oynamak istediği etkin rol sebebi ile olayın daha fazla büyümemesine ve Misır'la olan ilişkilerinin daha fazla bozulmamasına dikkat etti. Çünkü olay büyütüldüğü takdirde başta Mısır olmak üzere diğer Arap devletlerinin Sovyetler Birliği’ne yaklaşması kaçınılmaz olacaktı. Üstelik başta ABD olmak üzere (Arda, 2015: 189) diğer Batılı Devletler tarafindan Ortadoğu'da kurulacak savunma sistemine Türkiye'nin yanı sıra Arap Devletlerinin de katılması yönünde bir politika izlenmekteydi. Bu nedenle Türkiye ile Mısır arasında yapılan görüşmeden sonra ortak bir bildiri yayınlanmasına karar verildi. Yayınlanan ortak bildiride meydana gelen hadiseden dolayı duyulan üzüntü dile getirildi (Frrat ve Kürkçüoğlu, 2004: 621). Aradan çok geçmeden 1954 yılının ortalarında İngiltere ile Mısır arasında imzalanan anlaşma ile Mısır Hükümeti, Türkiye'ye yönelik bir saldırı olduğu zaman Süveyş üssünün yeniden açılmasına izin verdi. Mısır Hükümeti'nin bu kararı, iki ülke arasındaki gerginliğin azalmasına neden oldu (Yeşilbursa, 2010: 79).

\section{Sonuç ve Öneriler}

Türkiye, İkinci Dünya Savaşı'ndan sonra dış tehditlere karşı diğer devletlerle ittifak kurmak istedi. Bu nedenle 1951 yılında İngiltere, Amerika ve Fransa ile birlikte Ortadoğu Paktı Projesinin gerçekleşmesi için çalıştı. NATO'ya üyelik için başvurdu. Fakat Türkiye'nin bu girişimleri Mısır'ın politikasını değiştirmesine neden oldu. Çünkü Mısır'a göre Türkiye sömürgeci devletlerle işbirliği yapıyordu.

Osmanlı Hanedanı'na mensup kişiler tarafindan yönetilen Mısır'da 1952 yılında askeri bir darbe oldu. Darbeden sonra iktidar el değiştirdi. Askeri hükümet tarafından hanedanın tüm mallarına el konuldu. Hulusi Fuat Tugay, Türkiye tarafından 1951 yılında Kahire’ye büyükelçi olarak gönderilmişti. Hulusi Fuat Tugay'ın eşi Emine Tugay, Kral Faruk'un kuzeniydi. Kısa bir süre sonra askeri hükümet ülke genelinde bazı değişiklikler yaptı. Bu değişikliklerden biri de Müsadere Kanunu idi. Bu kanun ile Kral Faruk ve akrabalarının mallarına el konuldu. Misır'ın Türkiye büyükelçisi Hulusi Fuat Tugay'ın eşi Emine Hanım da bu kanundan olumsuz olarak etkilendi. Bu duruma sinirlenen ve öfkesini gizlemeyen Hulusi Fuat Tugay hakkında Misır basınında çok ağır ithamlar içeren haberler yayınlandı. Mısır basını, büyükelçi ve eşine karşı bir karalama kampanyası başlattı. Eşine ve kendisine yöneltilen suçlamalardan dolayı rahatsız olan ve artık Mısır'da kalamayacağını düşünen büyükelçi Hulusi Fuat Tugay, Dışişleri Bakanlığına başvurarak Mısır'dan alınmasını istedi. Dışişleri Bakanlığı, Hulusi Fuat Tugay’ın görev yerini değiştirmeye karar verdi ve alınan karar Türkiye'ye gelen büyükelçiye ve Mısır Hükümeti'ne bildirildi. Hulusi Fuat Tugay, işlerini düzenlemek için tekrar Mısır'a döndü.

Mısır Hükümeti 4 Ocak 1954'te aldığı bir kararla, Türkiye'nin Kahire büyükelçisi Hulusi Fuat Tugay'ın diplomatik ayrıcalıklarını kaldırdı. Mısırlı yöneticiler tarafından, Hulusi Fuat Tugay'ın 24 saat içinde Mısır'ı terk etmesi istendi. Mısır Hükümeti aldığı kararı bir telgrafla Türk Hükümeti'ne bildirdi. Hulusi Fuat Tugay'ın sınır dışı edilme kararı, Mısır gazetelerinde büyük başlıklarla yayınlandı. Mısır basını, büyükelçiyi Türk-Mısır ilişkilerinin bozulmasının en önemli sebebi olarak gösterdi. Olay yabancı basında da yer aldı. Yabancı basına göre Mısır diplomasi alanında acemice davranmıştı.

Mısır Hükümeti tarafından yapılan açıklamada Türkiye büyükelçisinin Mısır'dan çıkarılması kararının Türkiye'ye karşı olmayıp, büyükelçinin şahsına yönelik olduğu beyan edildi. Mısırlı yöneticilere göre, Büyükelçi Hulusi Fuat Tugay Türk-Mısır dostluğuna zarar 
vermişti ve bu nedenle büyükelçiyi sınır dışı etmek zorunda kalmışlardı. Hulusi Fuat Tugay, 5 Ocak 1954 günü Mısır'dan ayrıldı. Kahire havaalanına büyükelçiyi uğurlamak için İngiltere ve Belçika büyükelçilerinden başka hiç kimse gelmedi. Büyükelçi havaalanından ayrılmadan önce yaptığı açıklamada hiç kimsenin Türkiye ile Mısır arasındaki ilişkileri bozamayacağını, Mısırlı yöneticilerin hareketinin çocukça olduğunu söyledi. Mısır gümrük memurları tarafindan Büyükelçi Hulusi Fuat Tugay’nn kişisel eşyaları arandı. Dahası Mısırlı gazeteciler de havaalanına alındı. Mısırlı gazeteciler, bu haberin fotoğrafını çektiler. Ertesi gün Hulusi Fuat Tugay'ın gümrükte eşyalarının aranması ile ilgili haberler ve fotoğraflar Mısır basınında yer aldı. Siyasi çevreler, yerli ve yabancı basın bunu diplomatik saygısızlık olarak değerlendirdi.

Büyükelçinin geri çağrılacağını daha önceden Mısır’a bildiren Türk Dışişleri yetkilileri, Mısır Hükümetinin uluslararası kurallara aykırı hareket ettiğini söylediler. Çok geçmeden Mısır'ın Ankara'daki büyükelçisi Ahmet Hakkı, Dışişleri Bakanlığı'na çağrıldı. Dışişleri yetkilileri tarafından Mısır Büyükelçisi Ahmet Hakkı'ya hükümetine iletilmek üzere bir nota verildi. Mısır'ın Türkiye büyükelçisi Hulusi Fuat Tugay’ı sınır dışı etme kararı, Türkiye Büyük Millet Meclisi'nde de tartışıldı. Cumhuriyet Halk Partisi ve Köylü Partisi tarafından gensorular hazırlandı. Siyasi partiler ve basın, Hulusi Fuat Tugay'ın hareketlerini doğru bulmuyordu. Fakat söz konusu olan devlet itibarının zedelenmesi idi. Siyasi Partiler, Dışişleri Bakanı Fuat Köprülü'nün konu hakkında açıklama yapması istedi. Dışişleri Bakanı Fuat Köprülü, mecliste yaptığı konuşmada gerekli tedbirlerin alındığını söyledi. Ayrıca Mısır Hükümeti'ne bir nota verildiğini de sözlerine ekledi. Cumhuriyet Halk Partisi ve Köylü Partisi temsilcileri acilen bir tedbir alınmasını istediler. Fakat Dışş̧leri Bakanı Fuat Köprülü notanın cevabının henüz gelmediğini, bu nedenle konunun mecliste tartışılmasının hatalı olduğunu söyledi.

Türkiye, Ortadoğu'da kurulacak savunma sistemine Arap Devletlerinin de katılmasını istiyordu. Basına göre bu nedenle büyükelçi krizi fazla büyütülmedi. Mecliste Cumhuriyet Halk Partisi'nin ve Köylü Partisi'nin verdiği gensorular reddedildi. Hulusi Fuat Tugay ise şahsi itibarının ve meslek haysiyetinin rencide olduğunu belirterek emekliliğini istedi.

\section{Kaynakça}

Akşam Gazetesi: 2 Ocak 1954, 5 Ocak 1954, 6 Ocak 1954, 7 Ocak 1954, 8 Ocak 1954, 9 Ocak 1954, 10 Ocak 1954, , 13 Ocak 1954, 14 Ocak 1954, 17 Ocak 1954, 19 Ocak 1954, 20 Ocak 1954.

Armaoğlu, F. (Tarihsiz). 20. Yüzyıl Siyasi Tarihi, C.1-2, Ankara: Alkım Yayınevi.

Ataoğlu, E. (2008). Adnan Menderes Bir Başbakanın Trajik Sonu, İstanbul: Nokta Kitap.

Baş, A. (2015). Demokrat Parti Dönemi Türkiye-Misır İlişkileri (1950-1960), Gazi Üniversitesi Sosyal Bilimler Enstitüsü, Yayınlanmamış Doktora Tezi, Ankara.

CCA, Yer Bilgisi:82.8.10, Belge Tarihi: 29.01.1938, Dosya Ek: 107-98, Kurum:30.18.1.2 Kararlar Daire Başkanlığı.

CCA, Yer Bilgisi:118.4.1, Belge Tarihi: 29.01.1938, Kurum: Bakanlıklar Arası Tayin Daire Başkanlığı.

CCA, Yer Bilgisi:88.95.12, Belge Tarihi: 26.09.1939, Dosya Ek:107-110, Kurum:30.18.1.2/Kararlar Daire Başkanlığı.

CCA, Yer Bilgisi:161.15.6, Belge Tarihi: 13.07.1943, Kurum:30.11.1.0/Bakanlıklar Aras1 Tayin Daire Başkanlığ 1 .

Barrier Miner, 7 Ocak 1954.

Dağlar Macar, O. (2006), Birinci Dünya Savaşı'nda Osmanlı Ordularının Galiçya Cephesi'ne Gönderilmesi ve Cephe Gerisinde Yaşananlar, İstanbul Üniversitesi Atatürk Illkeleri ve İnklap Tarihi Enstitüsü Dergisi, Yakın Dönem Türkiye Araştırmaları, 5(10): 45-76. 
Fırat, M. ve Kürkçüoğlu Ö. (2004). Ortadoğu ile İlişkiler, Türk Dlş Politikası Kurtuluş Savaşı 'ndan Bugüne Olgular, Belgeler, Yorumlar (Edt. Baskın Oran), C.I, 1919-1980, 615635.

The Examiner, 8 Ocak 1954.

The Mercury, 6 Ocak 1954.

The Northern Miner, 7 Ocak 1954.

The West Australian, 6 Ocak 1954, 9 Ocak 1954.

Queensland Times, 6 Ocak 1954.

Milliyet Gazetesi: 23 Kasım 1953, 5 Ocak 1954, 6 Ocak 1954, 7 Ocak 1954, 8 Ocak 1954, 9 Ocak 1954, 10 Ocak 1954, 11 Ocak 1954, 12 Ocak 1954, 13 Ocak 1954, 14 Ocak 1954, 19 Ocak 1954, 20 Ocak 1954, 21 Ocak 1954, 26 Ocak 1954, 18 Nisan 1954.

Newcastle Morning Herald And Miners Advocate, 20 Ocak 1954.

Tuna, T.(2002). Adnan Menderes 'in Günlüğ̈̈, İstanbul: Şule Yayınları.

Ulus Gazetesi: 6 Ağustos 1939, 9 Ekim 1939, 21 Ocak 1944.

Yavuzalp, E. (1991). Menderes 'le Anılar, İstanbul: Bilgi Yayınevi.

Yeşilbursa, B. K. (2010). Demokrat Parti Dönemi Türkiye'nin Ortadoğu Politikası, History Studies, Ortadoğu Özel Sayıs1, ss.67-98. 